\title{
RPA3 Gene
}

National Cancer Institute

\section{Source}

National Cancer Institute. RPA3 Gene. NCI Thesaurus. Code C116637.

This gene plays a role in DNA replication, recombination and repair. 